\title{
Seasonal variability in the bacteriolytic capacity of the deposit feeder Arenicola marina: environmental correlates
}

\author{
Craig J. Plante ${ }^{1, *}$, Lawrence M. Mayer ${ }^{2}$ \\ ${ }^{1}$ Department of Biology, Grice Marine Biology Laboratory, University of Charleston, 205 Fort Johnson, Charleston, \\ South Carolina 29412, USA \\ ${ }^{2}$ Department of Oceanography, Darling Marine Center, University of Maine, Walpole, Maine 04573, USA
}

\begin{abstract}
Although deposit-feeding macrofauna consume and digest sedimentary bacteria, it is unclear whether feeding rates and digestion efficiencies are high enough to significantly impact the composition and abundance of bacteria in marine sediments. It is likely that both feeding rates and efficiency of digestion vary markedly through space and time. We used a turbidimetric assay to compare the rate of bacteriolysis by digestive fluids collected seasonally from the deposit-feeding polychaete Arenicola marina. Under standardized, experimental conditions, bacteriolytic rates represent concentrations of lytic agents. This concentration was found to vary significantly throughout the year $(p=$ 0.001 ), showing greater than a $2 \times$ range. Lytic agent concentration was positively correlated with bioavailable amino acid concentrations in the surface sediment $(r=0.85, p=0.03)$ but showed no apparent relationship to other proxies for food resources (e.g. chl a), sediment temperature, or gut throughput time. In vitro, temperature has been shown to have a strong positive influence on bacteriolytic rate. Temperature has no influence, however, on the in situ concentration of lytic agent in gut fluids, thus it appears that compensation for this temperature dependence is unimportant. These findings, combined with previous kinetics studies with $A$. marina gut fluids, predict that the quantitative influence of deposit feeding on the microbial ecology of sediments will exhibit clear seasonal variation.
\end{abstract}

KEY WORDS: Sedimentary bacteria $\cdot$ Trophic interactions $\cdot$ Deposit feeder Arenicola marina

\section{INTRODUCTION}

The critical importance of bacteria in the biogeochemical cycling and food web dynamics of marine sediments has spawned much recent interest in their ecology. Of central importance is the determination of factors influencing their production and removal and the quantification of both processes. Deposit-feeding macrofauna consume and digest sedimentary bacteria. Whether the feeding rate and digestion efficiency of deposit feeders are of magnitudes so as to significantly impact the abundance and composition of bacteria in marine sediments is equivocal. Although few studies have addressed such questions directly, the studies of Kemp (1987) and Bianchi \& Levinton (1981), for

·E-mail: plantec@cofc.edu instance, suggest that rate of removal of bacteria by macrofauna is insufficient to balance production in bulk sediments. In certain situations, however, such as when deposit feeders are abundant and ingestion is spatially restricted (e.g. to a thin veneer of surface sediment), their feeding can remove a significant portion of local bacterial production (e.g. Moriarty et al. 1985). With respect to qualitative effects, differential digestion of bacteria in macrofaunal grazers has been demonstrated (e.g. Findlay \& White 1983, Dobbs \& Guckert 1988, Duchene et al. 1988), although the impact on community compositions of bulk sediments remains unclear.

Environmental factors and covariables likely hold strong influence over rates of bacterial removal, yet, to date, have not been well considered. The kinetics studies of Plante et al. (1996) have shown that, in vitro, lytic 
rate of environmental isolates exposed to the digestive fluids of Arenicola marina increases exponentially with temperature and is also related to concentrations of both substrale and lytic factors according to MichaelisMenten kinetics. Thus, seasonal changes in ambient temperature and food quality are hypothesized to significantly influence rates of bacteriolysis in deposit feeders. One prediction might be that bacteriolytic rate should be lower, and thus the removal of bacterial production less, in winter when temperatures are at their lowest. The temperature dependence of enzymes in animals, however, may be offset by increased enzyme concentration (Hazel \& Prosser 1974, Somero et al. 1983). In fact, Seiderer et al. (1984) observed bacteriolytic activity in the black mussel Chromomytilus meridionalis only at cold $\left(<10^{\circ} \mathrm{C}\right)$ temperatures. This observation was hypothesized to be in response to the changing nature of food resources, i.e. low concentrations of phytoplankton were associated with cold upwelled waters so that a shift in digestive enzymes allowed the mussel to more efficiently utilize bacteria. In this study we begin to assess the effects of temporal variability on the rate and extent of bacteriolysis in deposit-feeder guts. We specifically test the prediction that the deposit feeder A. marina compensates for the reduced rate of bacteriolysis at cold temperature via increased concentrations of lytic agents. Further, we examine the relationships between food quality (protein, chl $a$, and pheopigment concentrations) and gut throughput time with bacteriolytic capacity.

\section{METHODS}

Specimen collection and preparation. Arenicola marina was collected at low tide from sediments surrounding Pratt's Island, Maine, USA. Animals were dissected on site; details of dissection procedures and designations of various gut sections for $A$. marina have been provided previously (Plante \& Mayer 1994). Specimens were collected on 6 dates $(21$ December 1992, 31 March, 28 June and 29 October 1993, and 19 May and 2 August 1994).

Gut throughput time estimation. Egestion rates (which roughly equal ingestion rates in plug-flow feeders that digest only a small portion of ingested material) were estimated by collecting fecal coils produced while lugworms were submerged and recently (within $1 \mathrm{~h}$ ) emersed. At $t_{0}$, coils were gently brushed away and marked with small, numbered flags. After intervals ranging from 30 to 115 min, new coils were collected using a small spatula. Quantitative sampling was only possible when fecal coils maintained their integrity over this interval, so that sampling was restricted to calm days without rain. After drying for
$>24$ h at $60^{\circ} \mathrm{C}$, samples were weighed and egestion rates (ER) were calculated and expressed as dry $g \mathrm{~h}^{-1}$. Gut throughput time (GTT) is inversely proportional to $E R$ and can be calculated if the capacity of the gut is known. We assumed that the gut was always full or nearly so, and therefore could estimate capacity by using the weight of sediment in the gut. This assumption will tend to result in an underestimation of GTT, but the error should be small in actively feeding animals (Plante \& Jumars 1993). We obtained these weights by first drying and weighing individual worms in glass vials, then combusting overnight at $550^{\circ} \mathrm{C}$. Difference between dry weight and combusted weight gave worm dry weight. Difference between combusted weight and vial weight gave gut sediment weight. Dry weights of scdimcnts that had beeñ removed with midgut fluid fractions were added to these values to get total gut capacity. GTT was then calculated as GTT $(\mathrm{h})=$ gut capacity $(\mathrm{g}) / \mathrm{ER}\left(\mathrm{g} \mathrm{h}^{-1}\right)$.

Temperature. Air, water and sediment (at $10 \mathrm{~cm}$ depth) temperatures were recorded in duplicate or triplicate on each of the 6 dates of collection.

Food quality measurements. Samples were collected from the top $3 \mathrm{~mm}$ of sediments to estimate food quality; we used protein, chl $a$, and pheopigments as measures of food quality. Although lugworms feed at depth, this surface layer provides a good estimation of current food quality as Arenicola marina can easily subduct, ingest and defecate sediments from the surface during the interval from one low tide to the next (Jakobsen 1967, Grossmann \& Reichardt 1991). Rijken (1979) demonstrated that very little mixing occurs with adjacent sediments as particles are transported from the surface, through the feeding funnel and ultimately into feces, and that this entire transit can take as little as $1.5 \mathrm{~h}$. All food quality samples were stored in the dark, on ice, during transport from the field to the lab.

Chl $a$ and pheopigment concentrations were determined by measuring fluorescence with and without $\mathrm{HCl}$ (Lorenzen 1966) using a Turner Fluorometer (Model 111). Samples were placed immediately into $90 \%$ acetone upon collection and allowed to extract. refrigerated and in the dark, at least overnight.

Protein samples were collected in $10 \mathrm{cc}$ syringe cores, frozen within $2 \mathrm{~h}$, and stored at $-70^{\circ} \mathrm{C}$ until analyzed. The method of Mayer et al. (1995) was used to quantify enzymatically hydrolyzable amino acids (EHAA). This method attempts to mimic digestion in an animal by employing digestive enzymes. Briefly, this method involved extracting a small amount (ca $0.1 \mathrm{~g}$ ) of freeze-dried sediment in phosphate buffer containing sodium arsenate. The poison is to inhibit microbial uptake of amino acids liberated in subsequent steps. Next, samples were incubated with nonspecific proteolytic enzyme (Proteinase-K, Sigma) to 
hydrolyze peptide bonds. The amino acids solubilized from the sediment include a wide range of states of polymerization, ranging from monomers to large polypeptides. Our primary interest is in low-molecularweight compounds that can be absorbed by an organism (i.e. monomers and small oligomers). The Proteinase-K must also be removed. Precipitation by trichloroacetic acid (TCA) was used to remove the higher-molecular-weight peptides and enzymes. The supernatant contains oligopeptides with $<7$ to 15 amino acids (Mayer et al. 1995). This supernatant was then subjected to total hydrolysis by adding $6 \mathrm{~N} \mathrm{HCl}$. Total amino acid concentration was then quantified by adding orthophthaldialdehyde (OPA), then measuring fluorescence at excitation-emission wavelengths of $340 / 455 \mathrm{~nm}$ in a spectrofluorometer. For calculation of amino acid concentrations on a weight-weight basis, we assumed an average molecular weight of $120 \mathrm{~g}$ $\mathrm{mol}^{-1}$.

Bacteria in sediments were not quantified; numbers and biomass of sedimentary bacteria, however, often correlate with protein levels (Meyer-Reil 1984, Mayer $\&$ Rice 1992). Because arenicolids have been shown to obtain most of their nutritional needs from sources other than bacteria (Hylleberg 1975, Plante et al. 1989), it is unlikely that deposit feeders would use as a functional or physiological cue any cellular component of bacteria alone.

Bacteriolytic assay. Bacteriolytic assays were performed using gut extracts of Arenicola marina by methods previously described (Plante \& Mayer 1994). Briefly, loss of turbidity in resuspensions of environmental isolates was used to measure relative lytic rates. Previous work (Plante et al. 1996) has demonstrated that bacteriolytic factors in $A$. marina show seasonally consistent temperature relationships, i.e. no allozymes or other seasonally induced lytic factors were evident. Therefore, when determined under reproducible, standardized conditions, lytic rates can be regarded as a measure of lytic agent concentrations. To compare the relative concentrations of lytic agents in seasonally collected lugworms, all experiments were conducted at room temperature (21 to $23^{\circ} \mathrm{C}$ ). To avoid confusion, we refer to in situ digestion of bacteria in lugworms as 'bacteriolytic capacity', while 'bacteriolytic rate' is used to refer to to the spectrophotometrically measured rate of lysis which, under standardized conditions, is an indication of relative concentration of bacteriolytic agents.

A pseudomonad, designated SS-1 (described previously in Plante \& Mayer 1994), isolated from surface sediments surrounding Arenicola marina was employed. Cells were cultured in filtered Marine Broth 2216 (Difco) at $25^{\circ} \mathrm{C}$ on a shaker table. Standard procedure was to harvest cells at $16 \mathrm{~h}$, with absorbances at
$450 \mathrm{~nm}\left(A_{450}\right)$ ranging from 1.4 to 1.8 (in broth, prior to washing). Cells were pelleted $(1200 \times g, 10 \mathrm{~min})$, washed in filtered, sterile seawater, and repelleted. Immediately prior to analysis, pellets were resuspended in $66 \mathrm{mM}$ phosphate buffer ( $\mathrm{PB}$; potassium phosphate, monobasic, $\mathrm{pH}=6.2$ ) ; these resuspensions were diluted with $\mathrm{PB}$ to give $A_{450}$ values between 0.6 and 0.7 This absorbance represents a concentration of about $1 \times 10^{8} \mathrm{SS}-1$ cells ml-1 Following centrifugation, $5 \mu \mathrm{l}$ of midgut fluid was added to $1.5 \mathrm{ml}$ of bacterial resuspension in disposable $1 \mathrm{~cm}$ polystyrene cuvettes. Midgut fluids were used in all assays of bacteriolytic rate. The spectrophotometer (Spectronic 2000, Bausch \& Lomb) was zeroed against PB; additions of $5 \mu \mathrm{l}$ of phosphate buffer to the bacterial resuspensions served as controls. Lysis was followed by optical clearing, with readings taken prior to additions and at $0,0.25,0.50$, $0.75,1,2,3$, and 5 min after addition of gut fluid or buffer. Initial lytic rates $\left(V_{1}\right)$ were determined from the linear portions of progress curves, spanning at least $30 \mathrm{~s}$ and 3 absorbance readings

Statistical analyses. One-way analyses of variance (ANOVA) were performed to determine whether lytic rates (= lytic concentrations), ER, or GTT varied among sampling dates. If a significant treatment effect was found by ANOVA, a posteriori multiple comparison tests were performed using Fisher's LSD test at an experimentwise $\alpha$ level of 0.05 . Multiple linear regression analysis and Pearson product-moment correlations were used to test for relationships between environmental (independent) variables and animal functional and physiological responses (i.e. ER, GTT and lytic agent concentration) as well as among the environmental variables. Both forward and backward stepwise selection strategies were used to determine predictor variables. Feeding rate parameters ER and GTT) were employed as both dependent and independent variables (versus lytic rate). All statistical tests were 2-tailed. All statistical tests were performed using SYSTAT (version 5.2.1) for the Macintosh computer.

\section{RESULTS}

Mean values of seasonal lytic rates (at room temperature) and environmental conditions are summarized in Table 1. Lytic rates (i.e. concentrations) varied by more than a factor of 2 . Food quality estimators showed marked temporal variability with EHAA values differing by a factor of 4 , chl a exhibiting a 7 -fold range and pheopigments ranging by more than a factor of 16 . Maxima for each were generally measured in spring and autumn, with lower values observed in late summer and winter. December chl a values, however, pro- 
Table 1. Means ( \pm SEM) of seasonal bacteriolytic rate, sediment temperature, gut throughput time, and concentrations of protein, chlorophyll $a$, and pheopigment

\begin{tabular}{|lcccrrr}
\hline Date & $\begin{array}{c}\text { Lytic rate } \\
\left(\mathrm{AU} \mathrm{min}^{-1}\right)\end{array}$ & $\begin{array}{c}\text { Temperature } \\
\left({ }^{\circ} \mathrm{C}\right)\end{array}$ & $\begin{array}{c}\text { GTT } \\
(\mathrm{h})\end{array}$ & $\begin{array}{r}\text { EHAA } \\
\left(\mathrm{mg} \mathrm{g}^{-1}\right)\end{array}$ & \multicolumn{1}{c}{$\begin{array}{r}\text { Chl } a \\
\left(\mathrm{mg} \mathrm{g}^{-1}\right)\end{array}$} & $\begin{array}{r}\text { Pheopigment } \\
\left(\mathrm{mg} \mathrm{g}^{-1}\right)\end{array}$ \\
\hline $31 \mathrm{Mar}$ & $0.211(0.038)$ & $4.2(0)$ & $1.34(0.23)$ & $0.34(0.03)$ & $2.16(0.58)$ & $0.72(0.32)$ \\
$19 \mathrm{May}$ & $0.272(0.019)$ & $10.8(0.3)$ & $1.39(0.30)$ & $0.65(0.06)$ & $15.03(2.09)$ & $11.29(1.75)$ \\
$28 \mathrm{Jun}$ & $0.210(0.007)$ & $12.5(0)$ & $1.01(0.16)$ & $0.49(0.05)$ & $4.49(1.34)$ & $5.26(0.96)$ \\
$3 \mathrm{Aug}$ & $0.120(0.033)$ & $20.3(1.1)$ & $1.18(0.12)$ & $0.26(0.23)$ & $4.57(0.76)$ & $3.00(0.56)$ \\
$29 \mathrm{Oct}$ & $0.265(0.020)$ & $8.9(0.1)$ & $1.47(0.43)$ & $0.95(0.11)$ & $10.07(0.87)$ & $11.83(1.16)$ \\
$21 \mathrm{Dec}$ & $0.157(0.019)$ & $3.8(0.3)$ & - & $0.24(0.02)$ & $12.47(0.77)$ & $6.71(0.48)$ \\
\hline
\end{tabular}

vided a notable exception to this trend. Temperature showed a $16.5^{\circ} \mathrm{C}$ range. Mean seasonal GTTs all fell between 1 and $1.5 \mathrm{~h}$ and did not vary significantly through time ( $p=0.492$; ANOVA). Similarly, ER did not show a significant seasonal variation $(p=0.243)$ with means differing by less than a factor of 2 .

Lytic agent concentrations showed significant ( $\mathrm{p}=$ 0.001; ANOVA) temporal variation (Fig. 1). Employing Fisher's LSD test for pairwise comparisons, the mean lytic rate of August samples was significantly lower than all other seasons except December, the December mean varied significantly only from the highest October mean. The 4 months exhibiting highest lytic rates, April, June, May and October, could not be distinguished from one another statistically.

Our initial prediction was that lytic agent concentration in gut fluids would increase as ambient temperature declined, i.e. that a negative correlation would be evident. No such correlation was observed (Fig. 2).

Similarly, it was apparent that mean lytic rate was not correlated with mean GTT for each date $(r=0.59$, $p=0.295$ ). We also attempted to correct GTT for individual body weight (dry g), but again no correlation

\section{SEASONAL LYTIC RATES}

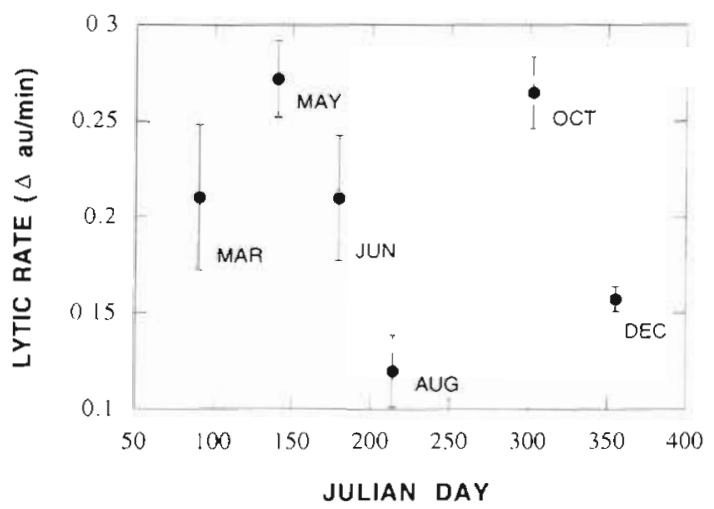

Fig. 1. Arenicola marina. Mean ( \pm 1 SEM) seasonal bacteriolytic rates (equal to concentration of lytic agent at constant laboratory temperature of $22^{\circ} \mathrm{C}$ ) of digestive fluids was evident $(r=0.001, p=0.999)$. Lytic rate of individual worms likewise was not correlated with GTT of the same individuals $(r=0.120, p=0.434$ ). Añalogous correlation tests employing $E R$, or ER adjusted to individual body dry weight, rather than GTT gave similar results in that no clear relationship emerged. Additionally, no correlation was found between individual animal size and lytic rate $(r=0.04, p=0.799)$, nor were animal size and GTT related $(r=0.18, p=0.246)$.

Lytic rate did, however, show some relationship with food quality. Lytic rate was positively and significantly correlated with sedimentary EHAA ( $\mathrm{r}=0.85, \mathrm{p}=0.033$ ) (Fig. 3). A better fit was obtained using the MichaelisMenten model, $V=V_{\operatorname{maxp}} S /\left(S+K_{\text {app}}\right)(\mathrm{r}=0.91, \mathrm{p}=$ $0.014)$, possibly indicating saturation of the lytic rate at around $0.6 \mathrm{mg}$ EHAA g ${ }^{-1}$; there are too few data, however, to confidently distinguish between the linear and non-linear models. Multiple regression analysis indicated that EHAA was the only significant predictor of lytic rate and the regression was not improved by addition of any other factors. On the other hand, no relationship was observed with chl a $(\mathrm{r}=0.70, \mathrm{p}=0.125)$.

LYTIC RATE VS. SEASONAL TEMPERATURE

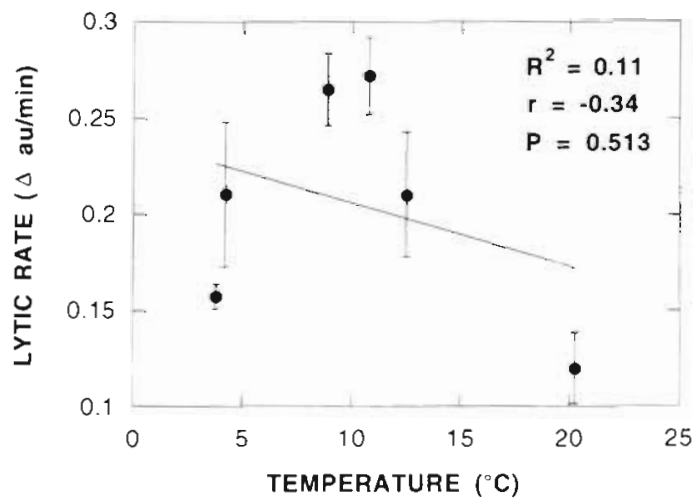

Fig. 2. Arenicola marina. No clear relationship was observed between mean ( \pm 1 SEM) bacteriolytic rate of lugworm gut fluids and temperature of sediments from which lugworms were collected 


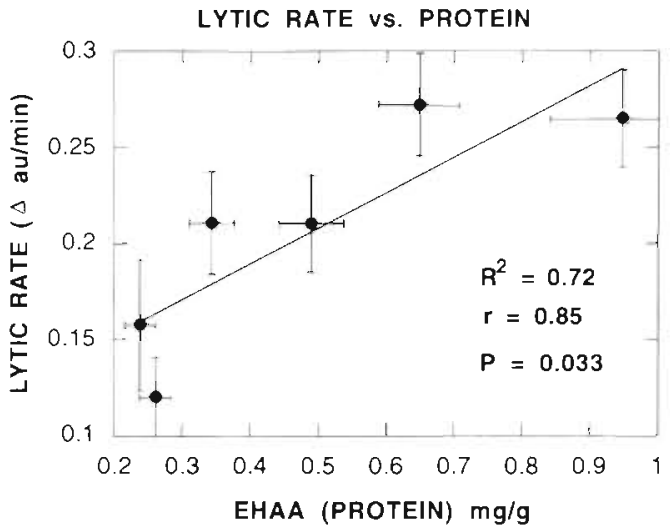

Fig. 3. Arenicola marina. A significant correlation was observed between mean ( \pm 1 SEM) bacteriolytic rate of lugworm gut fluids and EHAA concentration of sediments from which lugworms were collected

The correlation of lytic capacity with pheopigments was stronger $(r=0.74, p=0.095)$ but still not significant at an $\alpha$ of 0.05 .

No significant correlations were observed between Arenicola marina feeding rate (ER or GTT) and any of the food quality estimates (sedimentary EHAA, chl a and pheopigments), although the relationship of each with GTT was positive (Fig. 4). Similarly, no correlation with temperature was evident $(r=0.50, p=0.388)$. Nor were there significant correlations among these environmental parameters, with the exception of the significant correlation between chlorophyll and pheopigments $(r=0.84, p=0.036)$. In addition, the relationship between EHAA and pheopigments trended toward significance $(r=0.79, p=0.060)$.

\section{DISCUSSION}

Although lytic agent concentration varied significantly seasonally, this variation does not appear to be related to ambient temperature. The idea of compensatory production of additional or different enzymes has been supported for various marine poikilotherms (Hazel \& Prosser 1974, Shaklee et al. 1977). Previous work (Plante et al. 1996), however, has demonstrated that bacteriolytic factors in Arenicola marina show seasonally consistent temperature relationships, i.e. no allozymes or other seasonally induced lytic factors were evident. The data presented here suggest that compensation in the digestion of bacteria via enhanced production of lytic agent at low temperatures also is not important. It is likely, then, that there is marked seasonal variation in the extent and rate of bacteriolysis in the field.

Nutritional resource parameters, specifically bioavailable amino acid concentrations, are related to

\section{GTT VS. FOOD QUALITY PARAMETERS}

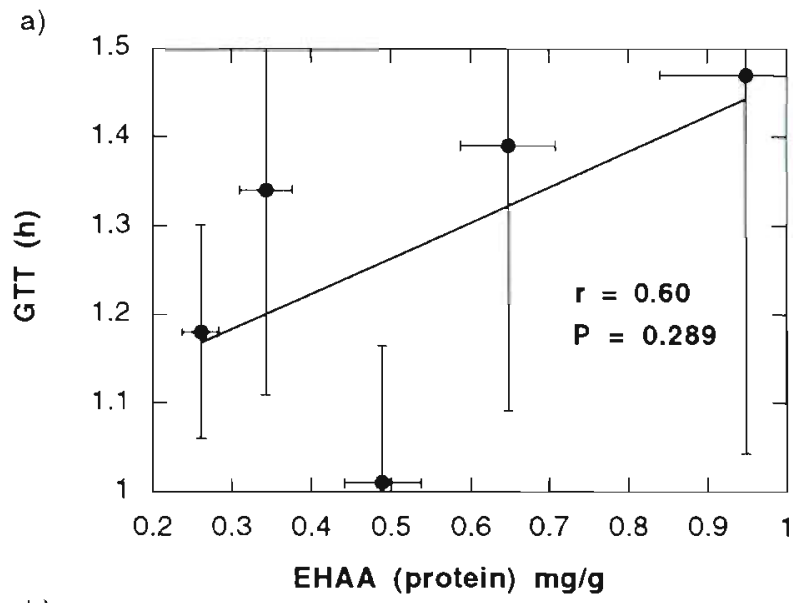

b)

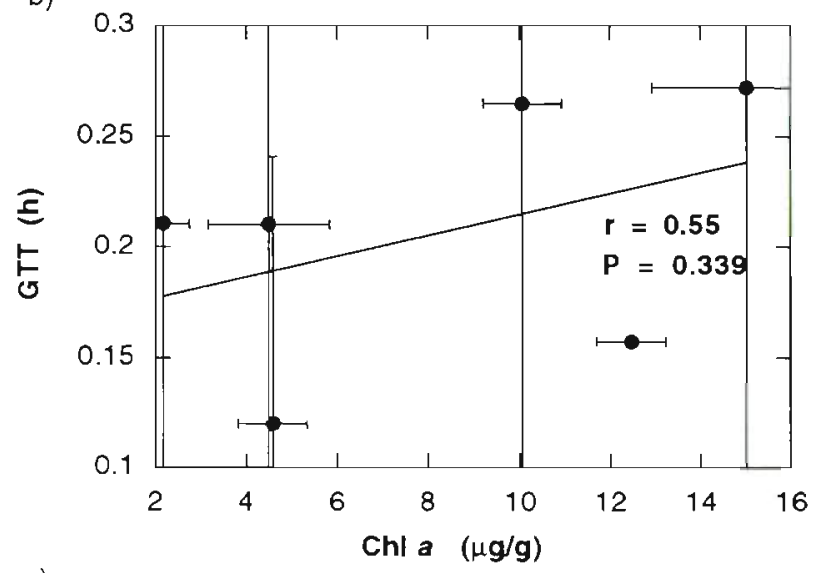

c)

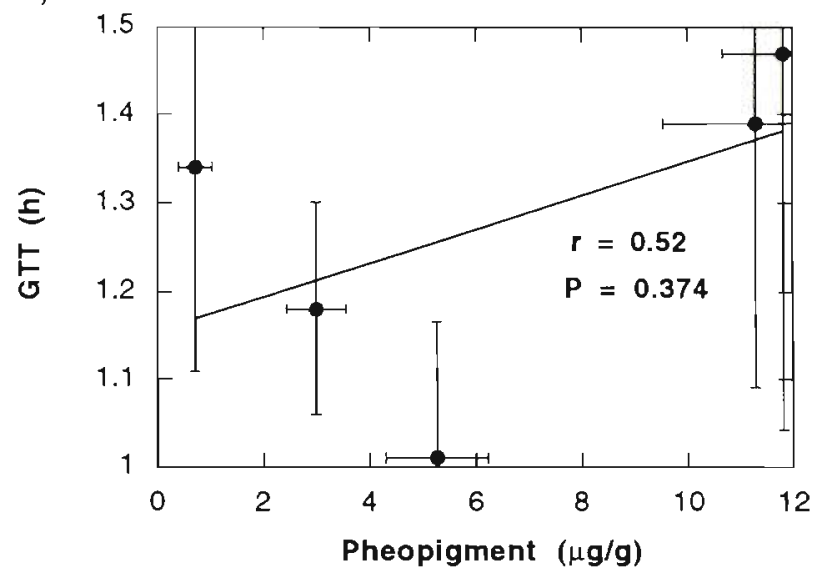

Fig. 4. Arenicola marina. Gut throughput time (GTT) showed a positive, linear relationship with concentrations of (a) EHAA, (b) chl a, and (c) pheopigment in sediments, although in no instance was the correlation significant. Error bars represent \pm 1 SEM

concentrations of lytic agents. A shortcoming of the present study is the absence of data regarding biomass or numbers of sedimentary bacteria. Previous work, however, has shown that only a subset of the bacteria 
are affected by the lytic factor being measured (Plante et al. 1996, C. J. Plante unpubl, data). Moreover, it is unlikely that bacterial cells constitute a major fraction of the protein in the intertidal sediments measured here (e.g. Meyer-Reil 1984, Mayer \& Rice 1992). There is, however, often a direct relationship between bacterial numbers and sedimentary protein. Bacterial biomass or numbers normally correlate well with various measures of sedimentary organic matter (Dale 1974 . Cole et al. 1988, Danovaro et al. 1994) including protein (e.g. Danovaro et al. 1993, Fabiano \& Danovaro 1994), although this has not always been observed (Danovaro et al. 1994). Whether an animal responds to bacterial food substrate with changing lytic activity depends upon (1) whether it has the ability to respond with specific subsets of its digestive apparatus, and (2) whether the lytic activity is due to an independent digestive agent relative to the other enzymes, emulsifiers, etc. in gut fluid. The lytic activity may simply be a function of an otherwise polyfunctional digestive agent, which the animal does regulate in response to overall food value (which we detect as EHAA). It is unlikely that deposit feeders would use as a cue any cellular component of bacteria alone, given that they constitute a relatively small fraction of sedimentary organic matter. This would be especially true in animals that obtain most of their nutritional needs from sources other than bacteria, as has been shown for other arenicolids (Hylleberg 1975, Plante et al. 1989).

Given that the response is related specifically to protein, and not correlated to chlorophyll or pheopigments, it is tempting to suggest that the lytic agent is a proteolytic enzyme. Furthermore, the distribution of bacteriolytic activity along the digestive tract (Plante \& Mayer 1994) closely resembles that for proteolytic enzymes in Arenicola marina (Longbottom 1970, C. J. Plante unpubl. data). Additional observations, however, suggest that the lytic factor is not an enzyme. Not only is the bacteriolytic factor resistant to denaturation via elevated temperature $(2 \times 1 \mathrm{~min}$ microwave to boiling; C. J. Plante unpubl. data) but also retains activity after pre-treatment with a general protease (Proteinase-K, Sigma No. P8044) (C. J. Plante unpubl.). Therefore, although the lytic factor may play some role in the digestion of proteins in general, it does not appear to be a proteolytic enzyme, but a compound simpler and more stable than an enzyme. The question of identity will remain until bacteriolytic agents can be isolated.

EHAA concentration was not significantly correlated with either sedimentary chl $a$ or pheopigment concentrations, however the relationship with pheopigments $(p=0.06)$ was considerably tighter than that with chl a $(p=0.37)$. Also in intertidal sediments of Maine, Mayer \& Rice (1992) observed a significant pheophytin-protein correlation. They also recorded low chl a/pheo- phytin ratios $(0.12$ to 0.48$)$ from which they concluded that in situ algal production was not an important control at their intertidal site. Our site, with relatively high pheopigment concentrations but also with all chl af pheopigment ratios $>0.85$, likely represents a situation in which labile algal and other protein sources dominate. Maxima for proxies of food quality (EHAA, chl a and pheopigment concentrations) were generally measured in spring and autumn, coincident with the expected period in temperate systems for sedimentation of planktonic algal blooms (Smetacek 1980, Mayer \& Rice 1992), as well as blooms of benthic diatoms (e.g. Gould \& Gallagher 1990, Trueblood et al. 1994).

The evidence that the concentration of lytic agent(s) varies seasonally suggests that bacterial communities are difforontially affected by deposit-feeder ingestion over space and time. Prior work has established under laboratory conditions a hyperbolic relationship between lytic factor concentration and lytic rate (Plante et al, 1996). It is unclear, however, whether in vivo concentrations of lytic factor would limit rate of lysis. Although our results suggest that ambient temperature is not correlated with lytic agent concentration, it has previously been shown that temperature has a clear effect on the kinetics of bacteriolysis by these lytic agents (Plante et al. 1996). Using the equations of Plante et al. (1996), we can convert the rates obtained here at the standard temperature of $22^{\circ} \mathrm{C}$ to those which would be predicted at in situ temperatures (Table 2). Using these converted rates (left column, Table 2), EHAA concentration alone no longer does well in explaining variation, whether a linear $\left(R^{2}=\right.$

Table 2. Means of seasonal bacteriolytic rates corrected for in situ temperature

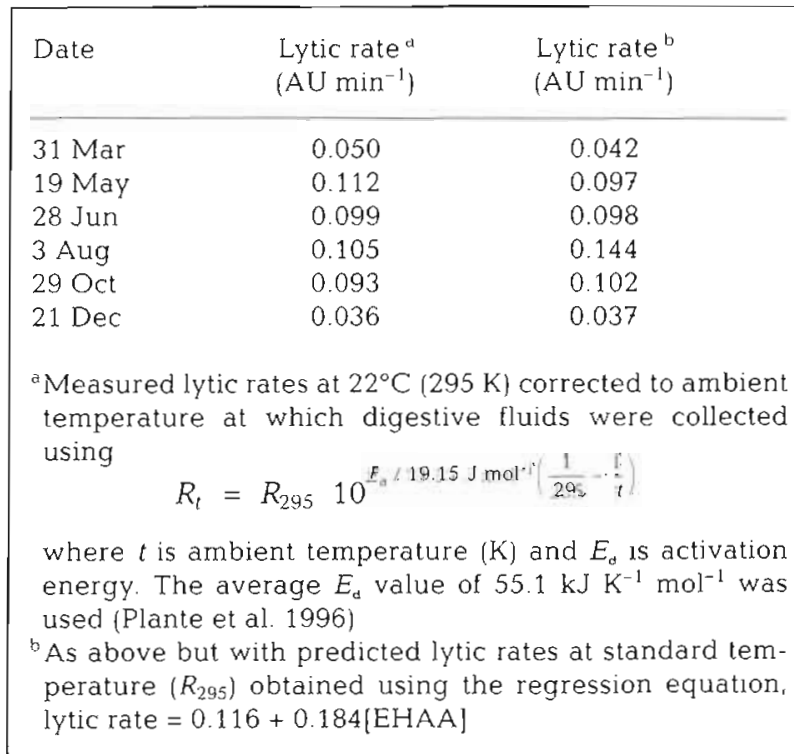


$0.21, p=0.33)$ or saturation model $\left(R^{2}=0.23, p \geqslant 0.05\right)$ is employed. On the other hand, temperature alone explains $78 \%$ of the variation assuming an exponential relationship (as indicated in Plante et al. 1996) ( $\mathrm{p}=$ $0.06)$, but $91 \%$ of the variation can be explained if EHAA concentration is added to the model $(p=0.03)$. Thus, it appears that ambient temperature is a dominant predictor of bacteriolysis in situ, while food quality (EHAA concentration) is significant but secondary via its relationship to lytic agent concentration.

The calculated range in bacteriolytic capacity corrected for temperature (Table 2 ) is 3 -fold, so that, given similar GTTs, the extent of removal could vary by a similar factor. Although the estimates for the role of deposit feeders in removing bacterial production range up to $10 \%$, in general, values are much lower (Bianchi \& Levinton 1981, Kemp 1987). Therefore, even if removal rates varied up to $3 \times$ more than the published estimates, macrofaunal removal would still be small relative to production rates. It should be noted that bacterial production rates also exhibit seasonal variation, at times seemingly correlated with protein (Meyer-Reil 1983) or other measures of nutritional resources (e.g. Meyer-Reil 1987. Cole et al. 1988) so that enhanced rate of bacteriolysis could be offset by increased bacterial production in sediments. Because digestion appears to be selective (Plante et al. 1996 , C. J. Plante unpubl. data), however, a low rate of bacterial removal relative to total production of sedimentary bacteria does not preclude the possibility that geochemical effects are large - certain bacteria exhibiting lower than average production may be greatly influenced by macrofaunal removal, particularly if they are highly susceptible to digestion.

In our analysis we treated the animals' feeding response (ER or GTT) as both an independent (potentially influencing lytic agent concentration) and dependent (potentially influenced by environmental variables) variable. GTT (or ER) and bacteriolytic concentration showed no significant correlation and thus do not appear to be directly linked.

Food quality and temperature are the most likely environmental factors dictating ingestion rate and GTT. Although previous field studies have documented seasonal differences in feeding rate (Linke 1939, Cadee 1976), laboratory experimentation has shown this variation to be largely independent of temperature in Arenicola marina, and to be rather a function of food content (Cadee 1976, de Wilde \& Berghuis 1979). Efforts to model deposit-feeder responses to food quality have typically focused on behavioral responses, with the assumption that an animal's physiological state does not vary (e.g. the reactor-theory models of Penry \& Jumars 1986, Dade et al. 1990). A non-monotonic relationship between ingestion rate and food resource is predicted (Phillips 1984, Dade et al. 1990). As food abundance increases from a minimum, an animal can achieve increased rates of energy gain by increasing food processing rate and decreasing throughput time to a point. There is an ingestion rate above which rate of gain decreases, however, because throughput time is insufficient for absorption. Laboratory tests have provided some confirmation of these predictions; Taghon \& Greene (1990) for the confamilial Abarenicola pacifica observed this intermediate peak at a protein concentration [using the Coomassie Blue (CB) method] of about 0.05 to $0.10 \mathrm{mg}$ $\mathrm{g}^{-1}$. Further, they provided evidence that this range of available protein may represent the critical concentration eliciting maximum sediment-processing rates for deposit feeders in general (Taghon \& Jumars 1984, Taghon \& Greene 1990). Our mean seasonal EHAA values ranged from 0.24 to $0.95 \mathrm{mg} \mathrm{g}^{-1}$ but would correspond to lower CB protein values (by a factor of 1.5 to $2 x_{\text {; }}$ Mayer et al. 1995) as measured by Taghon \& Greene (1990). Nevertheless, our calculated values still exceed the peak noted by Taghon \& Greene (1990), even when they are conservatively halved. Thus, a negative relationship between egestion rate and food quality (and a positive relationship between GTT and food quality) would be predicted for our samples. In contrast, field observations of $A$. marina fecal production have shown the opposite pattern $(10 \times$ increase from winter to summer; Cadee 1976) to that predicted and noted in the laboratory. Our data show no evidence of a significant seasonal change in feeding rate or gut throughput time, nor was there evidence of an intermediate peak.

The data presented here suggest a physiological response by a deposit feeder to changes in food quality in that the levels of at least 1 digestive catalyst are correlated with EHAA concentrations. On a seasonal scale, physiological adaptations may increase maximal rates of digestion and absorption ( $V_{\text {MAX }}$ and $W_{\text {MAX }}$ ) in response to increasing food resources so that digestive saturation does not occur. Over short time scales, there is a resource level at which some peak feeding rate occurs, however, this level may vary over longer time scales due to physiological acclimation (Mayzaud \& Poulet 1978). Higher food abundances then could be exploited by increasing ingestion rate. The observations of Cadee (1976) support this predicted relationship. Alternatively, higher food concentrations could be exploited by digestively degrading and absorbing a relatively greater fraction of ingested food (Penry \& Frost 1991), with little change in feeding rate. Our findings are more consistent with the latter scenario. We can attempt to reconcile our observed ingestion rate trends with the observations of Cadee (1976) by noting the extremely high day to day variability in Cadee's 
observations and the small number of days $(\mathrm{N}=5)$ for which we have feeding rate estimates. Much of the variation likely results from the behavioral responses in feeding rate to short-term fluctuations in resources (either a positive or negative relationship dependent upon the level of resources relative to the position of the peak) superimposed upon a longer-term acclimation to higher rates as resource levels increase. Laboratory experiments in which both the ingestive and digestive responses to varied food conditions are recorded over the long term are needed to further address the relationship between ingestion rate and resource level.

In addition to potential influences of bacteriolysis on the ecology of sedimentary microbes, digestion of bacteria likely is also of importance from the animal's perspective. Lysis of ingested bacteria may be either a strategy of predation or one of competition (or both). With the present data we cannot adequately address this issue since it is unclear whether the action of the lytic agent is specific to bacteria or whether lysis is incidental to degradation of some more general substrate type (e.g. protein). We can say, however, that our findings offer little challenge to the paradigm that bacterial biomass constitutes a minor fraction $(<10 \%$; Cammen 1980, 1989, Kemp 1990) of the bulk carbon requirements of deposit feeders. Although higher concentrations of catalytic factors can enhance the efficiency of digestion, since GTT did not vary significantly throughout the year, the effect of a higher efficiency is limited. At most a $2 \times$ increase in bacterial contribution could result from higher $V_{\text {MAx }}$ values since measured values of digestion efficiency for bacteria are already quite high, on average about $50 \%$ (Kemp 1990). Although the relative importance of bacteria may be much greater if other nutritional currencies, e.g. nitrogen, are considered (e.g. Phillips 1984, Cammen 1989), this constraint still holds.

If competition with bacteria in the gut for digestive products is the main concern, the same correlation between food resource and lytic agent concentrations would be predicted. The higher the food quantity the greater the amount of unabsorbed digestive product (Dade et al. 1990), which would stimulate growth and activity of competing microbes in the gut. Efficient elimination of ingested bacteria via stimulated production of lytic factors would provide one mechanism to combat this challenge.

Our results indicate significant seasonal differences in bacteriolytic agent concentration in Arenicola marina and that this concentration is correlated with sedimentary EHAA levels. These findings suggest numerous areas of further research. First, although the results of Plante et al. (1996) illustrate the kinetic effects of varying lytic agent concentrations, it is unclear whether a 2 to $3 \times$ change would significantly affect bacteriolytic rate in situ. Sediment incubations with gut fluids collected seasonally and at varied temperatures are needed. Second, identification of the agent(s) responsible for lysis would reveal whether a simple proteolytic agent is involved, allow cleaner kinetics experiments (see Plante et al. 1996) and provide further mechanistic information. Lastly, one of the chief goals of our research is to answer whether deposit-feeding macrofauna significantly influence the ecology of bacteria in bulk sediments. Studies such as the one presented here will help quantify the effect of macrofaunal ingestion through the provision of removal rate estimates which can be compared with rates of production by sedimentary microbes. Ultimately, however, animal removal or transplant experiments will be needed since 'baseline' data of this sort, i.e. bacterial growth rates in the absence of animals, needed for such comparisons are not available and cannot be obtained without such manipulations. Moreover, species-specific responses of bacteria to depositfeeder ingestion must be considered in order to address potential qualitative effects on microbial communities.

Acknowledgements. This work was supported by the National Science Foundation grants OCE 92-03063 and OCE 95-04505. This is contribution 133 of the Grice Marine Biological Laboratory, University of Charleston.

\section{LITERATURE CITED}

Bianchi TS, Levinton JS (1981) Nutrition and food limitation of deposit feeders. II. Differential effects of Hydrobia totteni and Lyanassa obsoleta on the microbial community. J Mar Res 39:547-556

Cadee GC (1976) Sediment reworking by Arenicola marina on tidal flats in the Dutch Wadden Sea. Neth J Sea Res 10: $440-460$

Cammen LM (1980) Ingestion rate: an empirical model for aquatic deposit feeders and detritivores. Oecologia 44 : $303-310$

Cammen LM (1989) The relationship between ingestion rate of deposit feeders and sediment nutritional value. In: Lopez GR, Taghon GL, Levinton JS (eds) Ecology of marine deposit feeders. Springer-Verlag, New York, p 210-222

Cole JJ, Findlay S, Pace ML (1988) Bacterial production in fresh and saltwater ecosystems: a cross-system overview Mar Ecol Prog Ser 43:1-10

Dade WB, Jumars PA, Penry DL (1990) Supply-side optimization: maximizing absorptive rates. In: Hughes RN (ed) Behavioral mechanisms of food selection. SpringerVerlag, London, p 531-556

Dale NC (1974) Bacteria in intertidal sediments: factors related to their distribution. Lumnol Dceanogr 19:509-518

Danovaro R, Fabiano M. Boyer M (1994) Seasonal changes of benthic bacteria in a seagrass bed (Posidonia oceanica) of the Ligurian Sea in relation to origin, composition and fate of the sediment organic matter Mar Brol 119: $489-500$ 
Danovaro R, Fabiano M, Della Croce N (1993) Labile organic matter and microbial biomasses in deep sea sediments (Eastern Mediterranean Sea). Deep Sea Res 40:953-965

Dobbs FC. Guckert JB (1988) Microbial food resources of the macrofaunal-deposit feeder Ptychodera bahamensis (Hemichordata: Enteropneusta). Mar Ecol Prog Ser 45: $127-136$

Duchene JC, Imbaud P, Delille D (1988) Associated bacterial microflora of a subantarctic polychaete worm Thelepus setosus. Arch Hydrobiol 112:221-231

Fabiano M, Danovaro R (1994) Composition of organic matter in sediments facing a river estuary (Tyrrhenian Sea): relationships with bacteria and microphytobenthic biomass. Hydrobiologia 277:71-84

Findlay RH, White DC (1983) The effects of feeding by the sand dollar Mellita quinquiesperforata (Leske) on the benthic microbial community. J Exp Mar Biol Ecol 72:25-41

Gould DM. Gallagher ED (1990) Field measurement of specific growth rate, biomass, and primary production of benthic diatoms of Savin Hill Cove, Boston. Limnol Oceanogr 35:1757-1770

Grossmann S, Reichardt W (1991) Impact of Arenicola marina on bacteria in intertidal sediments. Mar Ecol Prog Ser 77 : 85-93

Hazel J, Prosser CL (1974) Molecular mechanisms of temperature compensation in poikilotherms. Physiol Rev 54: $620-677$

Hylleberg $J$ (1975) Selective feeding by Abarenicola pacifica with notes on Abarenicola vagabunda and a concept of gardening in lugworms. Ophelia 14:113-137

Jakobsen $\mathrm{VH}$ (1967) The feeding of the lugworm Arenicola marina L. Quantitative studies. Ophelia 4:91-109

Kemp PF (1987) Potential impact on bacteria of grazing by a marine deposit feeder, and the fate of bacterial production. Mar Ecol Prog Ser 36:151-161

Kemp PF (1990) The fate of benthic bacterial production. Rev Aquat Sci 2:109-124

Linke O (1939) Die Biota des Jadebusenwattes Arenicola marina. Helgoländer Wiss Meeresunters 1:201-348

Longbottom MR (1970) Distributions of the digestive enzymes in the gut of Arenicola marina. J Mar Biol Ass UK 50: $121-128$

Lorenzen CJ (1966) A method for the continuous measurement of in vivo chlorophyll concentrations. Deep Sea Res 13:223-227

Mayer LM, Rice DL (1992) Early diagenesis of protein: a seasonal study. Limnol Oceanogr 37:280-295

Mayer LM, Schick LL, Sawyer T, Plante CJ, Jumars PA, Self RL (1995) Bioavailable amino acids in sediments: a biomimetic, kinetics-based approach. Limnol Oceanogr 40: $511-520$

Mayzaud P, Poulet SA (1978) The importance of the time factor in the response of zooplankton to varying concentrations of naturally occurring particulate matter. Limnol Oceanogr 23:1144-1154

Meyer-Reil LA (1983) Benthic response to sedimentation events during autumn to spring at a shallow water station in the Western Kiel Bight II. Analysis of benthic bacterial populations. Mar Biol 77:247-256

Meyer-Reil LA (1984) Bacterial biomass and heterotrophic activity in sediments and overlying waters. In: Hobbie JE,

Responsible Subject Editor: R. Sanders, Philadelphia, Pennsylvania, USA
Williams PJ LeB (eds) Heterotrophic activity in the sea. Plenum, New York, p 523-546

Meyer-Reil LA (1987) Seasonal and spatial distribution of extracellular enzymatic activities and microbial incorporation of dissolved organic substrates in marine sediments Appl Environ Microbiol 53:1748-1755

Moriarty DJW, Pollard PC, Hunt WG, Morlarty CM, Wassenberg TJ (1985) Productivity of bacteria and microalgae and the effect of grazing by holothurians in sediments on a coral reef flat. Mar Biol 85:293-300

Penry DL. Frost BW (1991) Chlorophyll a degradation by Calanus pacificus: dependence on ingestion rate and digestive acclimation to food resources. Limnol Oceanogr 36:147-159

Penry DL, Jumars PA (1986) Chemical reactor analysis and optimal digestion. BioSci 36:310-315

Phillips NW (1984) Compensatory intake can be consistent with an optimal foraging model. Am Nat 123:867-872

Plante CJ, Jumars PA (1993) Immunofluorescence assay for effects on abundance of a naturally occurring pseudomonad during passage through the gut of a marine deposit feeder, Abarenicola pacifica. Microb Ecol 26:247-266

Plante CJ, Jumars PA, Baross JA (1989) Rapid bacterial growth in the hindgut of a marine deposit feeder. Microb Ecol 18:29-44

Plante CJ, Mayer LM (1994) Distribution and efficiency of bacteriolysis in the gut of Arenicola marina and three additional deposit feeders. Mar Ecol Prog Ser 109:183-194

Plante CJ, Mayer LM, King GM (1996) The kinetics of bacteriolysis in the gut of the deposit feeder, Arenicola marina. Appl Environ Microbiol 62:1051-1057

Rijken M (1979) Food and food uptake in Arenicola marina. Neth J Sea Res 13:406-421

Seiderer LJ, Davis CL, Robb FT, Newell RC (1984) Utilisation of bacteria as nitrogen resource by kelp-bed mussel Choromytilus meridionalis. Mar Ecol Prog Ser 15:109-116

Shaklee JB, Christiansen JA, Sidell BD, Prosser CL, Whitt GS (1977) Molecular aspects of temperature acclimation in fish: contributions of changes in enzyme activities and isozyme patterns to metabolic reorganization in the green sunfish. J Exp Zool 201:1-20

Smetacek V (1980) Annual cycle of sedimentation in relation to phytoplankton ecology in western Kiel Bight. Ophella (Suppl) 1:65-76

Somero GN, Siebenaller JF, Hochachka PW (1983) Biochemical and physiological adaptations of deep-sea animals. In: Rowe G (ed) The sea, Vol 8, Deep-sea biology. John Wiley \& Sons, New York, p 261-330

Taghon GL, Greene RR (1990) Effects of sediment-protein concentration on feeding and growth rates of Abarenicola pacifica Healy et Wells (Polychaeta: Arenicolidae). J Exp Mar Biol Ecol 136:197-216

Taghon GL, Jumars PA (1984) Variable ingestion rate and its role in optimal foraging behavior of marine deposit feeders. Ecology 65:549-558

Trueblood DD, Gallagher ED, Gould DM (1994) Three stages of seasonal succession on the Savin Hill Cove mudflat, Boston Harbor. Limnol Oceanogr 39:1440-1454

Wilde PAWJ de, Berghuis EM (1979) Laboratory experiments on growth of juvenile lugworms, Arenicola marina. Neth J Sea Res 13:487-502

Manuscript first received: January 25, 1996

Revised version accepted: May 10, 1996 